\title{
Acute Deep Venous Thrombosis Associated with Acute Brucellosis: A Case Report
}

\author{
Akut Brusellozis ile İlişkili Akut Derin Ven Trombozu: Olgu sunumu
}

\author{
Sedat Koçak', Cesarettin Dikmetaş', Zerrin D. Dündar², Esma Erdemir', Recep Keşli4 \\ 'Department of Emergency, Meram Faculty of Medicine, Necmettin Erbakan University, Konya, Turkey \\ 2Department of Emergency, Konya Research and Education Hospital, Konya, Turkey \\ 3Department of Emergency, Kahramanmaraş Necip Fazil City Hospital, Kahramanmaraş, Turkey \\ ${ }^{4}$ Department of Microbiology, Konya Research and Education Hospital, Konya, Turkey
}

\section{ABSTRACT}

Brucellosis continues to be one of the most widespread zoonoses worldwide. Human brucellosis is a multisystem disease that may present with a broad spectrum of clinical manifestations, but it may also be asymptomatic with only serological evidence of infection. In this paper, a case report is presented of deep venous thrombosis (DVT) developing after a diagnosis of acute brucellosis in a young slaughterhouse worker. A 26-year-old man was diagnosed with DVT which had presented with the complaints of weakness and fever and a one-week history of pain and swelling in the right leg. Ultrasound revealed that the right femoral and popliteal veins were occluded with thrombi. Brucella was diagnosed using Rose-Bengal, tube agglutination, the Brucellacapt test and an enzyme-linked immunoassay using anti-Brucella abortus IgM/G antibody detection at another institution. Although rare, some infectious agents may cause vascular pathologies. These conditions may be life-threatening. Thus, it should be kept in mind that vascular complications may occur during infectious disease and patients should be monitored. Additionally, patients presenting with symptoms of DVT or similar vascular pathologies should be assessed for infectious agents, particularly Brucella and Salmonella, as well as other risk factors.

Keywords: Deep venous thrombosis, Brucellosis, venous thromboembolism

Received: 18.10.2011 Accepted: 19.12.2011

\section{ÖZET}

Brusellozis, dünya çapında en yaygın zoonozlardan biri olmayı sürdürmektedir. İnsan brusellozu bir çoklu sistem hastalığıdır ve çok çeşitli klinik bulgularla karşımıza gelebilir. Bazen enfeksiyon serolojik olarak pozitif olmasına rağmen asemptomatik olabilir. Burada 26 yaşında mezbaha işçisi bir erkek hastada, brusellozisi takiben gelişen derin ven trombozu (DVT) olgusu sunuldu. Hasta bir haftadır devam eden halsizlik, ateş ve sağ bacağında ağrı ve şişlik şikayeti ile başvurdu. Renkli doppler ultrasonografisinde sağ femoral ve popliteal venlerin trombüsle tıkalı olduğu görüldü. Brusella tanısı Rose-Bengal, tüp aglütinasyon, brucellacapt and enzim immunoassay anti-brucella abortus Ig M, G testleri ile, başka bir kurumda konmuştu. Nadiren de olsa bazı enfeksiyöz ajanların vasküler patolojilere neden olabildiği bildirilmiştir. Bunlar bazan hayatı tehdit edici olabilmektedir. Bu enfeksiyonların seyri esnasında vasküler komplikasyonlar gelişebileceği akılda tutulmalıdır ve hasta yakından izlenmelidir. Yine DVT ve benzeri patolojilerle başvuranlarda, diğer risk faktörleri yanında brusella ve salmonella gibi enfeksiyon ajanları da araştırılmalıdır.

Anahtar Kelimeler: Derin ven trombozu, Brusellozis, venöz tromboemboli

Geliş Tarihi: 18.10.2011 Kabul Tarihi: 19.12.2011

\section{Introduction}

Brucellosis continues to be one of the most widespread zoonoses worldwide (1). Human infections are common, particularly in the Mediterranean region and in developing countries (2). Human brucellosis is a multisystem disease that may present with a broad spectrum of clinical manifestations, but it may also be asymptomatic with only serological evidence of infection $(2,3)$. 
Most clinical signs of symptomatic brucellosis are non-specific and include fever, myalgia, weakness and fatigue (1). However, a wide variety of clinical presentations such as organ involvement and other complications have been reported in brucellosis $(2,3)$.

Vascular complications affecting the arteries and veins associated with Brucella infection have rarely been reported (3). Deep venous thrombosis (DVT) of the lower extremity associated with brucellosis is one of these complications $(1,4)$. Here, we describe a case of DVT of the right leg in association with acute brucellosis.

\section{Case Report}

A 26-year-old man was referred to our clinic with a pre-diagnosis of DVT by another healthcare unit to which he had presented with a one-week history of pain and swelling in the right leg. He had been working in a slaughterhouse. The pain radiated through the entire lower extremity starting from the thigh. After a while, the leg had become swollen. The patient's medical history included a diagnosis of brucellosis one month previously in the healthcare unit where he had presented to with complaints of weakness and fever. In that healthcare unit, the Rose-Bengal test was positive, the Brucella tube agglutination test result was 1/160, Brucellacapt was 1/320 positive (Vircell, S.L. Granada, Spain) and anti-Brucella abortus IgM/G (Euroimmun, Medizinische Labordiagnostika AG, Lübeck, Germany) was also positive by the enzyme immunoassay (EIA) method (Asys Expert Plus, Euroimmun Hitech, $\mathrm{GmbH}$, Austria). Abdominal ultrasound revealed an increase in the size of the liver and the spleen and increased diameter of the portal and splenic veins; markers for hepatitis were negative. He was put on rifampicin and doxycycline therapy.

Physical examination revealed a man in good general condition. His body temperature was $37.5^{\circ} \mathrm{C}$, pulse 100 beats per minute and blood pressure 150/100 mmHg. Peripheral pulses were normal in both lower extremities. The right lower extremity was hot and swollen. The Hoffman test was positive on the right lower extremity. Abdominal examination revealed a closed Traube space. No defensive or rebound tenderness was detected. His cardiopulmonary and neurological examinations were unremarkable.

Laboratory analyses revealed the following results: white blood cell count 7,100/ $\mu \mathrm{L}$, hemoglobin $13.3 \mathrm{~g} / \mathrm{dL}$, platelet count 306,000/ $\mu \mathrm{L}$, INR 1.29, PT 35.3 seconds, aPTT 28.6 seconds, urea 33 mg/dL, creatinine $0.78 \mathrm{mg} / \mathrm{dL}$, sodium $140 \mathrm{mEq} / \mathrm{l}$, potassium $4.2 \mathrm{mEq} / \mathrm{l}$, ALT $13 \mathrm{u} / \mathrm{l}$, AST 16 u/l. ECG showed a sinus rhythm. Color venous Doppler ultrasound of the right lower extremity revealed increased diameter of the right main, deep and superficial femoral veins, the popliteal vein and the cranial segments of the deep crural veins; the lumina these vessels were occluded with thrombi. There was no blood flow in the vascular lumina and there was no response in the veins to compression. The thrombi extended from the right main femoral vein to the vena saphena magna. The patient was diagnosed as having acute deep vein thrombosis.

Treatment with $60 \mathrm{mg}$ enoxaparin sodium s.c. was initiated. The patient underwent consultation in the Department of Cardiovascular
Surgery and was hospitalized. Anticardiolipin IgG and IgM were negative. Protein $C$ and protein $S$ were within the normal ranges. He was administered rifampicin 600 mg/day per oral, doxycycline 400 mg/ day per oral and heparin sodium 20.000 units/day subcutaneous in divided doses. He was also given warfarin sodium $5 \mathrm{mg} /$ day per oral simultaneously. Heparin was stopped when the INR values reached a therapeutic level. He was discharged on day nine of hospitalization with regression of complaints and physical examination findings. On discharge, he was prescribed warfarin 5 mg/day, rifampicin 600 mg/ day and doxycycline $100 \mathrm{mg} /$ day per oral.

\section{Discussion}

Brucellosis represents a serious public health problem in many developing countries (3). Brucella are small Gram-negative bacteria capable of surviving and even multiplying within the cells of the mononuclear phagocytic system, which can explain the high frequency of long-lasting illness, complications and relapses $(5,6)$. The incubation period is between 7 days and 3 months, although incubation periods as long as 10 months have also been reported (7). Brucellosis is a systemic infection with a wide clinical spectrum ranging from asymptomatic forms to severe cases causing death (2). The infection usually manifests itself as a febrile syndrome with no apparent focus, chills, malaise and myalgia (3).

Venous or arterial involvement is rare in brucellosis. The reported cases include abdominal artery thrombosis, popliteal artery aneurysm, deep vein thrombosis, portal vein thrombosis and cerebral vein thrombosis (1-3, 8-11). Species leading to vascular complications have been identified as B. melitensis, B. abortus and B. suis (1). There are other cases of acute DVT with other infectious agents found in the literature. Other agents causing DVT are Salmonella typhimurium varicella zoster virus and HIV (12-14).

These infections may cause DVT due to the following mechanisms: invasion of the surrounding tissue by the infectious agent, inflammation caused by the infectious process in the surrounding tissue, direct damage to the endothelium caused by the infectious agent and temporary hypercoagulopathy caused by the infectious agent (1). No pathological results for the etiological factors that cause thrombosis were found in our case, including protein $\mathrm{C}$, protein $\mathrm{S}$ and anticardiolipin IgG and IgM. No local infection focus that may have affected the deep venous structures of the right leg was found in our case. It was believed that DVT in this case was associated with Brucella infection, as there were no risk factors for venous thrombosis, including immobilization, history of previous DVT, recent surgical intervention or local tissue trauma.

\section{Conclusion}

Although rare, some infectious agents may cause vascular pathologies. These conditions may be life-threatening. Thus, it should be kept in mind that vascular complications may occur during infectious diseases and patients should be monitored. Additionally, patients presenting with symptoms of DVT or similar vascular pathologies should be assessed for infectious agents, particularly Brucella and Salmonella, as well as other risk factors. 


\section{Conflict of interest}

No conflict of interest was declared by the authors.

\section{References}

1. Odeh M, Pick N, Oliven A. Deep venous thrombosis associated with acute brucellosis: A case report. Angiology 2000; 51: 253-6. [CrossRef]

2. Young EJ. Human brucellosis. Rev Infect Dis 1983; 5: 821-42. [CrossRef]

3. Colmenero JD, Reguera JM, Martos F, Sanchez-de-Mora D, Delgado M, Causse $M$, et al. Complications associated with brucella melitensis infection: A study of 530 cases. Medicine 1996; 75: 195-211. [CrossRef]

4. Marfil-Rivera LJ, Mares Ramirez MA, Mora-Brondo P, et al. Deep venous thrombosis in a patient with brucellosis and probable lupoid inhibitor. Rev Invest Clin 1986; 38: 311-5.

5. Ocon P, Reguera JM, Morata P, Juarez C, Alonso A, Colmenero JD. Phagocytic cell function in active brucellosis. Infect Immun 1994; 62: 910-4.

6. Spink WW. Some biological and clinical problems related to intracellular parasitism in brucellosis. N Eng J Med 1952; 247: 603-10. [CrossRef]

7. Gerghiou PR, Young EJ. Prolonged incubation in brucellosis. Lancet 1991; 337: 1543. [CrossRef]
8. Sanchez-Gonzales J, Garcia-Delange T, Martos F, Colmenero JD. Thrombosis of the abdominal aorta secondary to Brucella spondylitis. Infection 1996; 24: 261-2. [CrossRef]

9. Gelfand MS, Kaiser AB, Dale WA. Localized brucellosis: popliteal artery aneurysm, mediastinitis, dementia and pneumonia. Rev Infect Dis 1989; 11: 783-8. [CrossRef]

10. Gregori J, Ortuño J, Ruiz Rivas JL, Arenas M. Brucellosis and portal thrombosis. Rev Esp Enferm Dig 1990; 78: 187-8.

11. Zaidan R, Al Tahan AR. Cerebral venous thrombosis: A new manifestation of neurobrucellosis. Clin Infect Dis 1999; 28: 399-400. [CrossRef]

12. Ceyhan M, Kanra G, Benderlioglu B, Secmeer G, Hicsonmez G, Kirazli S. Transient protein $S$ deficiency with deep venous thrombosis during Salmonella typhimurium infection. Arch Dis Child 1993; 68: 138-9. [CrossRef]

13. Gogos CA, Apostolidou E, Bassaris HP, Vagenakis AG. Three cases of varicella thrombophlebitis as a complication of varicella zoster virus infection. Eur J Clin Microbiol Infect Dis 1993; 12: 43-5. [CrossRef]

14. Becker DM, Saunders TJ, Wispelwey B, Schain DC. Case report: venous thromboembolism in AIDS. Am J Med 1992; 303: 395-7. [CrossRef] 